\title{
Human herpesviruses in the cornea
}

Stephen B Kaye, Kevin Baker, Richard Bonshek, Henry Maseruka, Esther Grinfeld, Andrew Tullo, David L Easty, Colin A Hart

\begin{abstract}
Aims-To determine the sensitivity and specificity of culture, immunohistochemistry (IHC), the polymerase chain reaction (PCR), and in situ hybridisation (ISH) for detecting herpes simplex virus (HSV-1) in the cornea of patients undergoing penetrating keratoplasty. To compare the incidence of $\mathrm{HSV}-1$ in the cornea with that of varicella zoster virus (VZV), cytomegalovirus (CMV), and EpsteinBarr virus (EBV).

Methods-The corneas of 110 patients, 52 with a documented history of herpes keratitis (HSK) and 58 with non-herpetic corneal disease, were investigated using IHC, PCR, ISH, and culture.

Results-HSV-1 DNA and antigen were detected in $82 \%$ and $74 \%$ respectively, of corneas of patients with HSK and in $22 \%$ and $15 \%$ of corneas of patients with no history of HSK. The sensitivity of PCR and IHC was $82 \%$ and $74 \%$ with a specificity of $78 \%$ and $85 \%$, respectively. HSV-1 DNA and antigen were found more frequently and in increased amounts in corneas of patients with a short interval between their last attack of HSK and surgery. There was a good correlation between PCR and IHC in $71 \%$. HSV-1 was isolated by culture in $2 \%$. Latency associated transcripts were not detected using ISH. Evidence of VZV DNA or antigen was found significantly more frequently in the corneas of patients with a history of HSK $(\mathrm{p}<0.001)$. No evidence of $\mathrm{EBV}$ or $\mathrm{CMV}$ was found in any cornea.

Conclusions-PCR and IHC are both sensitive for the detection of HSV-1 in the cornea. A combination of PCR and IHC increases the specificity for the diagnosis of HSK to $97 \%$. HSV-1 appears to be slowly removed from the cornea. VZV and HSV-1 may co-infect the cornea.

(Br F Ophthalmol 2000;84:563-571)
\end{abstract}

Several methods including viral culture, ${ }^{1-6}$ polymerase chain reaction (PCR), ${ }^{6-13}$ immunohistochemistry (IHC), ${ }^{13-15}$ and in situ hybridisation (ISH), ${ }^{10}{ }^{16}$ have been used for the detection of herpes simplex virus type 1 (HSV-1) in the human cornea. These techniques, however, differ in sensitivity and specificity, detect different components of $\mathrm{HSV}-1$, and as a result have been inconclusive about the state of HSV-1 in the cornea and its relation to clinical disease. For example, while culture remains the standard for the detection of infectious virus, it only indirectly detects latent virus - that is, it requires the virus to reactivate from a latent state. Similarly, IHC will not detect latent virus, and the presence of HSV-1 antigen does not necessarily imply infectious virus. Although the detection of HSV-1 DNA by PCR provides evidence for the presence of viral DNA, it does not imply functional virus as only part of the viral DNA may be present; nor does it distinguish between latent and infectious virus. While there is evidence to suggest that the cornea may support a neuronal type of HSV-1 latency, ${ }^{17}$ the establishment of HSV-1 latency in the human cornea has not been entirely conclusive. During HSV-1 latency, viral gene expression is restricted, apart from the production of the latency associated transcripts (LAT), which are important for efficient viral reactivation. ${ }^{18}$ The production of LAT increases during latency and is considered a marker of latency. Although these transcripts have been detected using RNA PCR, ${ }^{6}{ }^{19}$ they have not yet been shown to be present in the human cornea by ISH. It has been difficult, therefore, based on individual laboratory tests on a corneal specimen removed at penetrating keratoplasty, to make the premorbid diagnosis of herpes simplex keratitis (HSK). This has frustrated the implementation of many of these methods in clinical practice. If HSK is clinically defined as a history of recurrent dendritic or geographic corneal ulceration and the development of stromal scarring, then it becomes possible to characterise the laboratory features of the corneas of patients with a history of HSK.

In order, therefore, to evaluate these techniques for the investigation of $\mathrm{HSV}-1$ in corneal disease, we undertook a three centre study on patients undergoing penetrating keratoplasty. This was to determine and compare the sensitivity and specificity of viral culture, the PCR, IHC, and ISH for the detection of HSV-1 in the cornea of patients with and without a history of herpes simplex keratitis (HSK). For comparison, and because of the finding of other human herpesviruses in the cornea, keratoplasty specimens were also investigated for evidence of varicella zoster virus 
$(\mathrm{VZV}),{ }^{20-24}$ Epstein-Barr virus (EBV), ${ }^{725} 26$ and human cytomegalovirus (CMV). ${ }^{27} 28$

\section{Methods}

PATIENT POPULATION

The corneas of 110 patients undergoing penetrating keratoplasty between 1993 and 1997 for visually disabling corneal disease were investigated. Fifty two patients with a history of HSK were included, of which nine had repeat corneal transplants secondary to recurrent HSK and/or corneal graft rejection. In 22 of these patients HSV-1 had been isolated from a corneal-conjunctival swab at some stage in the patient's history; in the remaining 21 cases (excluding those patients who had repeat regrafts) it was not possible to trace whether a swab had at some stage been collected at the time of recurrence of HSK. The results of those patients who had had a positive isolate were, however, compared with those in whom a culture result could not be traced. Fifty eight patients with no clinical history of HSK (nonHSK) were included who had endothelial dysfunction due to Fuchs' endothelial dystrophy, aphakic or pseudophakic bullous keratopathy (20), lattice corneal dystrophy (three), trauma (two), keratoconus (13), unilateral vascularised corneal scars of unknown aetiology (three), bacterial corneal ulceration (four), and bilateral interstitial keratitis (five). Eight patients had repeat penetrating keratoplasty. Nineteen eye bank corneas unsuitable for transplantation because of endothelial counts less than 2000 cells $/ \mathrm{mm}^{2}$ were also included.

\section{SPECIMEN COLLECTION}

The cornea was divided through its centre into equal quadrants, one of which was placed in growth medium (10\% fetal calf serum) and the remaining quadrants snap frozen in liquid nitrogen.

CULTURE

The quadrant was dissected into fragments, placed on confluent monolayers of Vero cells with and without $15 \mu \mathrm{M}$ azacytidine, ${ }^{29}$ and the medium from the tissue culture was also subcultured.

POLYMERASE CHAIN REACTION (PCR)

The quadrant was diced with two sterile blades, digested with proteinase $\mathrm{K}$, followed by phenol chloroform extraction as previously described. ${ }^{6}$ Extracted DNA was resuspended in $50 \mu \mathrm{l}$ deionised water at a concentration of $10-50 \mathrm{ng} / \mu \mathrm{l}$ and $5 \mu \mathrm{l}$ used for each PCR. ${ }^{6}{ }^{30}$ After heating to $94^{\circ} \mathrm{C}$ for 3 minutes, thermocycling (Hybaid thermocycler) of 40 cycles at $94^{\circ} \mathrm{C}$ for 30 seconds, $55^{\circ} \mathrm{C}$ for 30 seconds, and $72^{\circ} \mathrm{C}$ for 1 minute, followed by a final extension at $72^{\circ} \mathrm{C}$ for 5 minutes was carried out. Oligonucleotide primers and probes used (Gibco BRL) were for human CMV gene 29, EBV nuclear antigen, ${ }^{32} \mathrm{HSV}-1$ thymidine kinase gene, ${ }^{33} \mathrm{VZV}$ major capsid region, ${ }^{23}$ and human hypoxanthine guanine phosphoribosyl transferase gene (HPRT). ${ }^{64}$ Single PCR reactions were done for each primer pair.
Sensitivity of the whole procedure (extraction of DNA and PCR) was determined by a plaque forming dilution assay. For the HSV-1 TK primers a reduction in primer concentration, from $0.4 \mu \mathrm{M}$ to $0.2 \mu \mathrm{M}$, reduced the sensitivity from $0.2-1$ pfu (plaque forming units $/ \mathrm{ml}$ to $10 \mathrm{pfu} / \mathrm{ml}$. Sensitivity of the PCR procedure alone was determined by diluting HSV-1 DNA (Sigma) in human DNA (extracted from human embryonic lung cell fibroblasts (MRC5 Whittaker)). This resulted in a detection sensitivity of one to five genomes of HSV-1 in 200 ng human DNA. As with the pfu assay, reducing the HSV-1 TK primer concentration from $0.4 \mu \mathrm{M}$ to $0.2 \mu \mathrm{M}$, reduced the sensitivity of the PCR to 50-100 genome equivalents. Both concentrations of HSV-1 TK primers $(0.4 \mu \mathrm{M}$ and $0.2 \mu \mathrm{M})$ were used for all specimens in order to semiquantify the PCR results. In addition, 5 and 50 genomes of HSV-1 DNA in $200 \mathrm{ng}$ of human DNA were used as templates to compare sample signal intensity. Similarly, the sensitivity of the VZV, EBV, and CMV PCR was between 5-10 genome equivalents. HSV-1, VZV, CMV, EBV, and human DNA were used to assess the specificity of the different oligonucleotide primers, respectively. No non-specific amplification occurred using the various combinations of DNA and primers, or with water, following the DNA extraction procedure. In particular, no cross reactivity occurred between the VZV, HSV-1 primers, and the HSV-1 and VZV DNA.

\section{IMMUNOHISTOCHEMISTRY (IHC) AND}

HISTOPATHOLOGY

Cryostat sections $(6 \mu \mathrm{m})$ were mounted on to 3-aminopropyltriethoxy silane (APES) coated slides and a standard avidin-biotin peroxidase complex technique ${ }^{35}{ }^{36}$ was used. Sections were incubated with 1:25 (v:v) anti-HSV-1 (clone NCL-HSV-1 20.7.1) and 1:30 (v:v) anti-VZV (clone NCL-VZV C90.2.8) (Novacastra Ltd, UK). Controls included an irrelevant primary antibody (anti-human desmin) (Dako Ltd), rabbit serum (Sigma), sections from encephalitic brain (HSV-1) and myocardial endothelium (disseminated VZV), and HSV-1 and VZV infected human embryonic lung cell fibroblasts. No cross reactivity occurred between the VZV and HSV-1 antibodies. Staining was graded as negative, positive, or strongly positive.

Specimens were grouped according to the histological classification of Holbach et $a l,{ }^{13}$ into active avascular (IA), active vascular (IB), inactive avascular (IIA), and inactive vascular (IIB). Corneas with no inflammation, scarring, or vascularisation, such as endothelial failure, were classified as group IIIA.

IN SITU HYBRIDISATION

ISH was performed only on corneas that had evidence of HSV-1DNA. The segment was fixed for 1 hour at $4^{\circ} \mathrm{C}$ in $4 \%$ paraformaldehyde before dehydration, wax embedding, and sectioning onto APES treated slides. Positive controls included trigeminal ganglia from mice which had been inoculated at least 1 month 
$\begin{array}{llllllllllllll}1 & 2 & 3 & 4 & 5 & 6 & 7 & 8 & 9 & 10 & 11 & 12 & 13 & 14\end{array}$

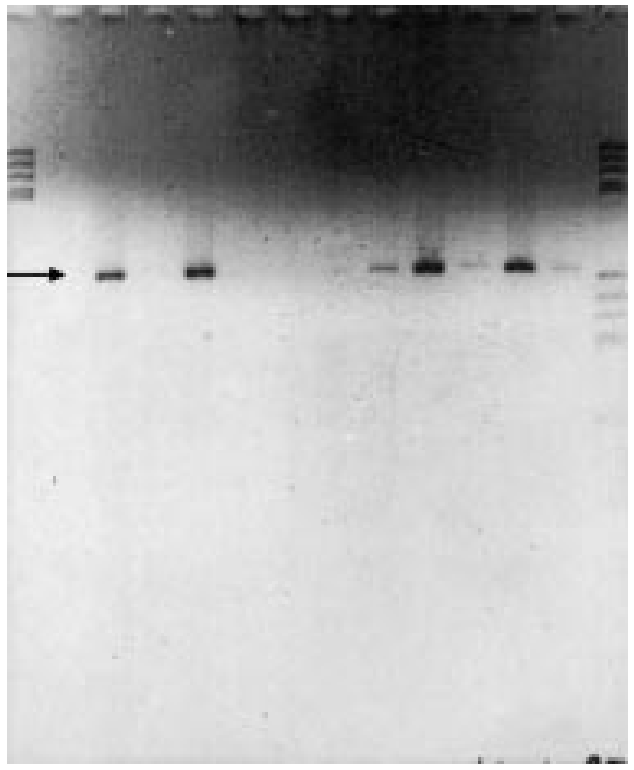

Figure 1 PCR with HSV-1 TK primers (287 bp amplicon: arrow) 3\% agarose gel, ethidium bromide stain. DNA marker, Hae III pBR322 digest (lanes 1 and 14). HSV-1 positive controls (50 and 5 genome equivalents) (lanes 3 and 13) and negative control (lane 2). Corneal specimens from patients with a history of HSK and a relatively short history from last episode of HSK to surgery show a strong signal (lanes 5, 10, and 12), compared with a weaker signal in patients where the interval form HSK to surgery is much longer (lanes 8 and 9), or a patient with no history of HSK but with evidence of HSV-1 DNA, where the signal is also much less (lane 11). Corneas from patients with no history of HSK and no evidence of HSV-1 DNA (lanes 4, 6, 7).

previously by corneal scarification ${ }^{37}$ with $10^{4}$ pfu of HSV-1 strain McKrae, and Vero cells infected with HSV-1. Trigeminal ganglia of mock infected mice and non-infected Vero cells were used as negative controls. A method based on that of Hukkanen et $a l^{38}$ was used. Only LAT transcription was investigated, using a 195 base LAT probe, which was cloned into the vector pUBS, linearised with Hind III, and labelled with digoxigenin using the RNA labelling kit (Boehringer Mannheim). A slide was

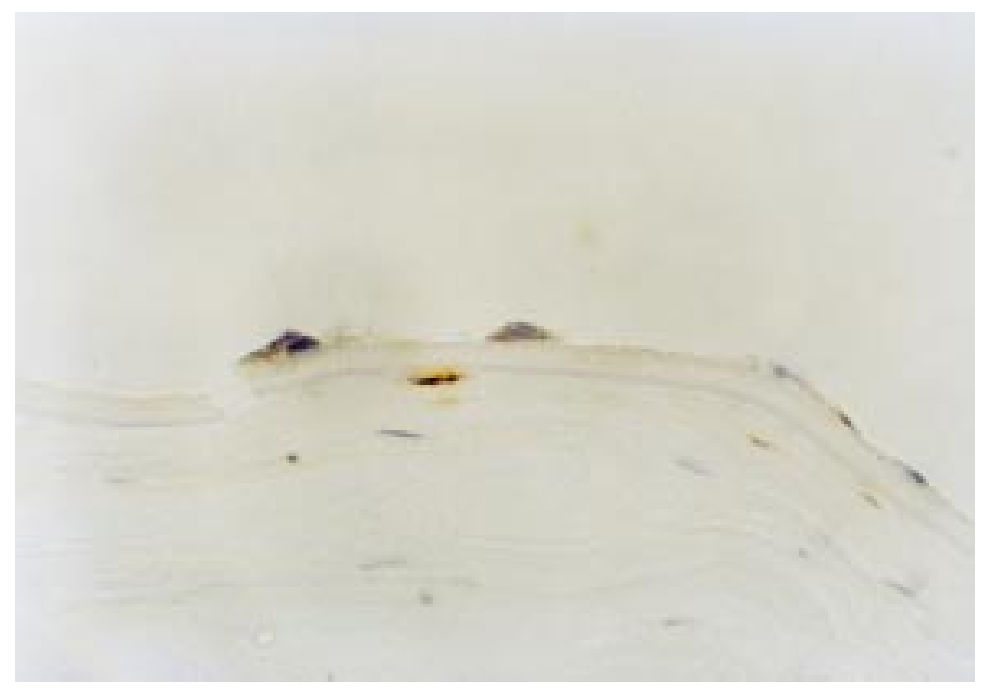

Figure 2 Immunohistochemistry: HSV-1 antibody, DAB and haematoxylin counterstain. Posterior stromal keratocyte and endothelial cell positivity with HSV-1 antibody. No inflammation is present (original magnification $\times 320$ ). reserved for hybridisation to a DIG labelled poly dT probe to confirm that there was RNA remaining in the tissue. LAT positive cells were detected using a sheep anti-digoxigenin antibody conjugated to alkaline phosphatase and a $\mathrm{BCIP} / \mathrm{NBT}$ substrate colour reaction.

STATISTICAL ANALYSIS

A $\chi^{2}$ test was used. Where the expected frequency in any cell was less than 5, a Fisher's exact test (two tailed) was used.

\section{Results}

Culture was performed on 110 corneas, PCR on 106 corneas and 19 eye bank corneas, IHC on 72 , and ISH on 15 HSK corneas containing HSV-1 DNA. Owing to logistical problems with difficulties in storage and transport between centres, only 68 corneas all underwent PCR, IHC, and viral culture.

\section{VIRAL CULTURE}

HSV-1 was isolated from one cornea after 4 days in culture. This cornea also had evidence of HSV-1 antigen (see below).

\section{POLYMERASE CHAIN REACTION}

The DNA in all samples (apart from controls) was amplified using the HPRT primers, confirming the presence of human DNA and the absence of inhibitors of the PCR. No amplification of negative controls occurred using the HSV-1, VZV, CMV, EBV, or HPRT primers. Using a PCR sensitivity of one genome equivalent or $0.2 \mathrm{pfu} / \mathrm{ml}, \mathrm{HSV}-1 \mathrm{DNA}$ was detected in $42 / 51$ (82\%) HSK corneas and $12 / 55(22 \%)$ non-herpetic corneas $(\mathrm{p}<0.0001)$ (Fig 1). Using a sensitivity of 50 genome equivalents (or $10 \mathrm{pfu} / \mathrm{ml}$ ), HSV-1 was detected in $14 / 51$ of the HSK corneas but in none of the non-HSK corneas $(\mathrm{p}<0.0001)$.

There were nine HSK corneas that were PCR negative. The corneas of three of these patients had evidence of HSV-1 antigen and one patient had evidence of VZV DNA. These patients had their last attack of HSK, ranging between 2 months and 20 years before surgery, with a median time of 7.5 years.

The non-HSK corneas which had evidence of HSV-1 DNA, comprised four corneas from patients with endothelial dysfunction, two from patients with keratoconus, two patients with unilateral vascularised focal corneal scars of unknown aetiology, and four from patients who had had previous corneal transplants for an alkali burn, endothelial failure, and keratoconus. Their grafts had failed, three of the four from rejection episodes. The two patients with keratoconus had a history of recurrent herpes simplex labialis. One of these patients developed a dendritic ulcer with a positive culture in the recipient part of the graft 3 months after surgery, and the cornea of the other patient had evidence of HSV-1 antigen. There appeared to be no significant difference in the incidence of HSV-1 DNA between those patients who had had culture proved HSK and those in whom the culture could not be documented-that is, 20/22 compared with 22/29 (at least one 
Table 1 Localisation of HSV-1 antigen by IHC within the cornea. Number of specimens that had evidence of antigen. Parentheses indicate antigen that was confined to the respective layer

\begin{tabular}{llll}
\hline & Epithelium & Stroma & Endothelium \\
\hline IHC+ve & $1(0)$ & $32(28)$ & $6(2)$ \\
IHC-ve & 71 & 40 & 66
\end{tabular}

Table 2 Sensitivity and specificity of PCR, IHC, culture, and ISH for the detection of HSV-1. Strong PCR refers to at least 50 genome equivalents in sample before amplification and strong IHC indicates a strong IHC signal

\begin{tabular}{lcc}
\hline Test & Sensitivity (\%) & Specificity (\%) \\
\hline PCR & 82 & 78 \\
IHC & 74 & 85 \\
Both PCR and IHC+ve & 68 & 97 \\
Culture & 2 & 100 \\
In situ (LAT) & 0 & - \\
Strong PCR & 28 & 100 \\
Strong IHC & 54 & 88 \\
Either PCR or IHC+ve & 95 & 63 \\
\hline
\end{tabular}

LAT $=$ latency associated transcript.

Table 3 Correlation between PCR and IHC in HSK and non-HSK corneas

\begin{tabular}{lll}
\hline Disease & Agree & Disagree \\
\hline HSK & $28(74 \%)$ & $10(26 \%)$ \\
Non-HSK & $20(67 \%)$ & $10(33 \%)$ \\
Total & $48(71 \%)$ & $20(29 \%)$ \\
\hline
\end{tabular}

Table 4 Variation between PCR and IHC in HSK and non-HSK corneas

\begin{tabular}{|c|c|c|}
\hline & $P C R+v e, I H C-v e$ & $P C R-v e, I H C+v e$ \\
\hline HSK & $18 \%(7 / 38)$ & $8 \%(3 / 38)$ \\
\hline Non-HSK & $20 \%(6 / 30)$ & $13 \%(4 / 30)$ \\
\hline
\end{tabular}

genome equivalent) $(p=0.12)$ or $5 / 22$ and $8 / 29$ (for at least 50 genome equivalents) $(\mathrm{p}=0.15)$.

IN SITU HYBRIDISATION

ISH was carried out on the corneas of 15 patients with HSK, 13 of which had more than 50 genome equivalents of HSV-1 DNA. No cells were positive for LAT in any of 30 sections carried out for each segment. In all cases the positive controls had LAT containing neurons and the negative controls were negative.

IMMUNOHISTOCHEMISTRY

IHC was performed on the corneas of 39 patients with a history of HSK, 29 of which showed evidence of HSV-1 antigen (Fig 2). Of these, 21 gave a strong signal. Ten HSK corneas were IHC negative, seven of which had evidence of HSV-1 DNA. IHC was performed on 33 non-herpetic corneas, five of which had

Table 5 Interval (years) from last recurrence of HSK to surgery (excluding regrafts). $P C R$ and IHC results. Strong PCR refers to at least 50 genome equivalent in sample before amplification

\begin{tabular}{lllll}
\hline & Median time (years) & Mean time (years) & Range (years) \\
\hline PCR & & & & \\
& strong positive & 0.75 & 0.65 & $0.0-1.0$ \\
& positive & 1.75 & 1.80 & $0.1-3$ \\
& negative & 5.00 & 8.56 & $1-20$ \\
IHC & & & \\
& strong positive & 0.75 & 0.86 & $0-2.5$ \\
& positive & 3.00 & 4.28 & $1-15$ \\
& negative & 2.00 & 6.40 & $0.1-20$ \\
\hline
\end{tabular}

evidence of HSV-1 antigen, comprising three patients with a history of endothelial failure, one of whom had a repeat corneal transplant due to endothelial failure 2 months after the first transplant dysfunction, one patient with a history of interstitial keratitis, and one patient with keratoconus who also had evidence of HSV-1 DNA. HSV-1 antigen was found significantly more frequently in the corneas of patients with a history of HSK than those with no history of HSK $(p<0.0001)$. HSV-1 antigen was found significantly more frequently in the stroma than in the epithelium or endothelium $(p<0.0001)$. Only one patient who had clinically active disease at the time of surgery (with a HSV-1 isolate from the cornea) had evidence of HSV-1 antigen in the epithelium as well as the stroma (Table 1). As with the incidence of HSV-1 DNA, there was no significant difference in the incidence of HSV-1 antigen between patients with culture proved HSK $(13 / 17)$ and those in whom a culture could not be documented $(16 / 22)(\mathrm{p}=0.16)$.

\section{HISTOPATHOLOGY}

Corneas from patients with a history of HSK were found more frequently in groups $1 \mathrm{~A}$ and 1B (active inflammation), while the corneas from patients with no history of HSK were found more frequently in groups 2 and 3 $(p<0.001)$. HSV-1 DNA and antigen were found more frequently in groups $1 \mathrm{~A}$ and $1 \mathrm{~B}$ $(p<0.05)$. For patients with HSK, there was no difference in the incidence of HSV-1 DNA or antigen, between histological groups 1 to 3 $(p=0.2)$.

SENSITIVITY AND SPECIFICITY OF PCR, IHC, CULTURE, AND ISH FOR THE DETECTION OF HSV-1 This was determined using as the standard the clinical diagnosis of HSK, as defined in the methods. The sensitivity and specificity of PCR for HSV-1 was $82 \%$ and $78 \%$, respectively (Table 2 ). The sensitivity and specificity for a higher threshold of HSV-1 DNA detection (greater than 50 genome equivalents) was $28 \%$ and $100 \%$, respectively. The sensitivity of IHC was $74 \%$ with a specificity of $85 \%$. Using only a strong signal, the sensitivity of IHC was $54 \%$ with a specificity of $88 \%$. The sensitivity and specificity of culture was $2 \%$ and $100 \%$, respectively.

PCR VERSUS IHC

There was a good overall correlation between PCR and IHC, with agreement in $71 \%$ of cases (Table 3). In particular, $28 / 38 \quad(74 \%)$ of corneas from patients with a history of HSK were either both IHC and PCR positive or negative. Likewise, $67 \%(20 / 30)$ of corneas from patients with no history of HSK were either both IHC and PCR positive or negative (Table 4). There was no significant difference in the level of agreement or disagreement between PCR and IHC in patients with or without a history of HSK $(p=0.35)$.

INTERVAL FROM LAST HSK TO SURGERY

HSV-1 DNA was detected more frequently in those corneas that had the last herpetic episode 


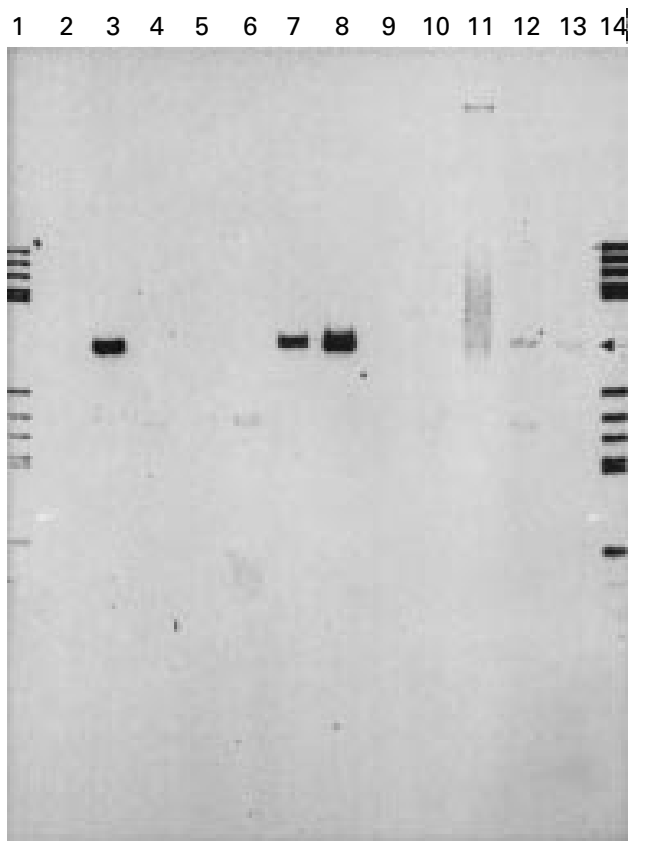

Figure 3 PCR with VZV gene 29 primers (333 bp amplicon: arrow). DNA marker, Hae III pBR322 digest (lanes 1 and 14). VZV positive control (lane 3), negative control (lane 2). Corneal samples from patients with a history of HSK and evidence of VZV (lanes 7, 8, 11-13). Patients with history HSK but no evidence VZV lanes 4-6, and 9, 10).

within 2 years of surgery (Table 5) - that is, patients who had less than 50 genome equivalents of HSV-1 DNA in their corneas had a median and average time interval of 1.75 and 1.80 years, while those with greater than 50 genome equivalents had a median and average time interval of 0.75 and 0.65 years, respectively $(\mathrm{p}=0.0005)$. Those who had no evidence of HSV-1 DNA had a median and average time interval of 5.00 and 8.56 years, which was significantly longer than patients who had evidence of HSV-1 DNA ( $p=0.01)$; both for those with greater than 50 genome equivalents $(p=0.0076)$ and less than 50 genome equivalents $(p=0.017)$. Likewise, patients with HSK

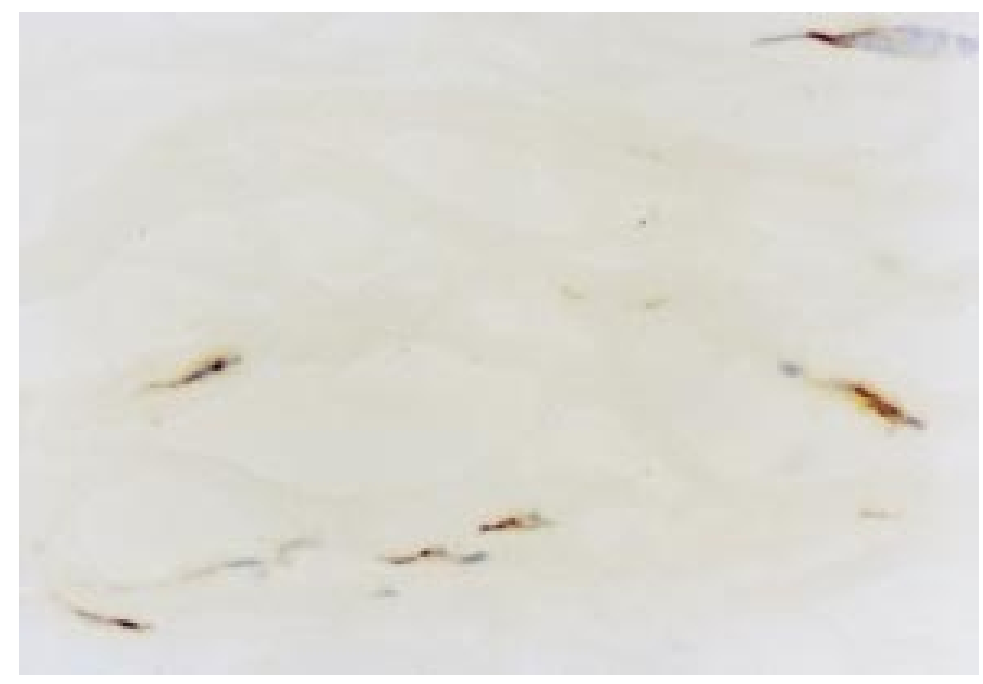

Figure 4 Immunohistochemistry: VZV antibody, DAB and haematoxylin counterstain. The labelling is associated with keratocyte nuclei and nuclear membrane. No inflammation is present (original magnification $\times 800$ ). who were found to have HSV-1 antigen, had had their last episode of HSK, 0.86 years (strong positive) and 4.28 years (positive) $(p=0.109)$ (median time 0.75 and 3 years respectively) before surgery, compared with those patients who had no evidence of HSV-1 antigen, who had had their last attack 6.40 years (median 2.5 years) before surgery $(\mathrm{p}=0.057)$.

EYE BANK CORNEA

Two of $19(10.5 \%)$ corneas had evidence of HSV-1 DNA. HSV-1 was not isolated by culture from any of these corneas.

\section{PATIENTS WITH REPEAT PENETRATING}

\section{KERATOPLASTY}

Nine patients with previous HSK had a repeat penetrating keratoplasty for corneal graft failure. Two patients had had recurrent HSK, one of which was complicated by a secondary bacterial keratitis. The remaining seven patients had had corneal graft rejection, which in four patients was associated with recurrent HSK. The corneas of eight of these nine patients had HSV-1 DNA, of which five had evidence of HSV-1 antigen; the remaining patient's cornea had evidence of both HSV-1 and VZV antigen. There was no significant difference in the incidence of HSV-1 DNA or antigen in the corneas of those patients with a history of HSK, compared with patients with a history of HSK who had repeat penetrating keratoplasty $(\mathrm{p}=0.34$ and $\mathrm{p}=0.32$ respectively).

Of the eight patients with non-HSK corneal disease who had repeat penetrating keratoplasty, four had evidence of HSV-1 DNA and one had evidence of HSV-1 antigen. Two of these patients had rejection episodes, one patient had developed a herpetic ulcer resulting in scarring and irregular astigmatism and two patients had endothelial failure at 2 and 5 months after keratoplasty. There was a trend towards an increase in the presence of HSV-1 DNA in non-herpetic regrafts, compared with either eye bank corneas $(\mathrm{p}=0.08)$ or other nonherpetic corneas $(p=0.12)$.

CYTOMEGALOVIRUS AND EPSTEIN-BARR VIRUS No evidence of CMV or EBV DNA was detected in the corneas of 89 patients.

VARICELLA ZOSTER VIRUS

Immunohistochemistry

The corneas of four out of 36 patients with a history of HSK had evidence of VZV antigen (Fig 3), three of which also had evidence of HSV-1 antigen. One out of 29 non-HSK corneas had evidence of both VZV and HSV-1 antigen, but not DNA.

\section{Polymerase chain reaction}

The corneas of 12 patients with a history of HSK had evidence of VZV DNA (Fig 4), 10 of which also had evidence of HSV-1 DNA. One out of 24 non-HSK corneas tested had evidence of VZV DNA as well as HSV-1 DNA.

Evidence of VZV, either by PCR or by IHC, was found in 16 of 70 corneas. One patient had evidence of VZV by both PCR and IHC, 11 
patients by PCR only, and four patients by IHC only. VZV was found significantly more frequently in the corneas of patients with a clinical history of HSK than in patients with no clinical history of HSK $(p<0.001)$. Furthermore, the corneas of 15 of these 16 patients had evidence of HSV-1, nine by both PCR and IHC, four by PCR, and two by IHC. One patient with a clinical and culture documented history of HSK and laboratory evidence of HSV-1, both by PCR and IHC, also had evidence of VZV both by PCR and IHC.

\section{Discussion}

Although culture remains the standard for the detection of a productive infection by HSV-1, it is an insensitive technique, particularly for the isolation of HSV-1 from the deeper layers of the cornea and may be incapable of detecting a latent infection. Easty et $a l^{3}$ found that HSV-1 was isolated more frequently from areas of scarring and that treatment may influence HSV-1 isolation. Indeed the frequency of virus isolation has decreased in the most recent studies - that is, Tullo et $a l^{2}$ 6/9 (1985), Easty et $a l^{3}$ 10/34 (1987), Coupes et al ${ }^{4} 2 / 8$ (1986), Cook et $a l^{5} 1 / 8$ (1986), Kaye et $a l^{6} \quad 1 / 10$ (1991), and $1 / 52$ in this study, possibly due to differences in antiviral treatment. Combining all studies gives an overall isolation rate of $17 \%$, which reflects the insensitivity of culture for the detection of HSV-1 within the cornea.

POLYMERASE CHAIN REACTION

The results of this study and others ${ }^{6-13}$ show that PCR is a sensitive method for detecting HSV-1 DNA in the cornea. PCR had a high detection rate in patients with previous HSK, with a sensitivity of $82 \%$ and a specificity of $78 \%$. This detection rate decreased in those patients who had a long interval between their last attack of HSK and surgery - that is, the median time in those patients with evidence of HSV-1 DNA was less than 2 years, while those patients with a negative result had a median interval of 7.5 years. This is in keeping with the results of O'Brien et al, ${ }^{39}$ who found a decrease in the detection of HSV-1 DNA from $100 \%$ to $30 \%$, at 4 months post-infection of rabbit corneas. A similar trend was present for HSV-1 antigen, which suggests that both HSV-1 DNA and antigen have a limited life within the cornea. This contrasts with the trigeminal ganglion where $\mathrm{HSV}-1$ readily establishes a latent infection and appears to have an unlimited lifespan.

HSV-1 DNA was detected in approximately a 10-50 times greater amount in HSK than non-HSK corneas, particularly where the time interval from the last attack to surgery was relatively short. In essence, reducing the sensitivity of the PCR to detect a threshold of 50 genomes increased the specificity of the PCR to $100 \%$. This supports the concept ${ }^{40}{ }^{41}$ that a critical amount of HSV-1 is required before the infection becomes clinically evident. The difference in sensitivity thresholds would thus account for the detection of HSV-1 DNA in the corneas of patients with no clinical history of HSK and is in keeping with previous work.
Cantin $e t a l{ }^{9}$ found an incidence of $4 / 11$, Rong et $a l^{8}(0 / 6)$, Kaye et $a l^{6}(5 / 10)$, Laycock et al ${ }^{10}$ $(0 / 5)$, and Alvarado et al ${ }^{12}(0 / 15)$. Taken together with the results of the present study gives an overall incidence of $21 \%$ of HSV-1 DNA in non-HSK diseased corneas. It is of note that one patient with keratoconus, who had evidence of HSV-1 DNA and antigen, developed a herpetic ulcer at the graft-host interface, 3 months postoperatively. Whether evidence of HSV-1 in the cornea is prognostic for the development of HSK after penetrating keratoplasty ${ }^{42}$ is unclear and is the subject of an ongoing study.

IMMUNOHISTOCHEMISTRY

IHC showed good sensitivity and specificity for the detection of HSV-1 - that is, $74 \%$ and $85 \%$, respectively. As with PCR, patients with a history of HSK, who had no evidence of HSV-1 antigen in their corneas, had a longer interval to surgery. There was likewise, a greater preponderance of strong IHC signals in the corneas of those patients with a shorter duration from their last episode of HSK to surgery.

TYPE OF INFLAMMATION AND CELLULAR INFILTRATE

The corneas from patients with HSK fell mainly within histological groups $1 \mathrm{~A}$ and $1 \mathrm{~B}$, similar to the findings of Holbach et al. ${ }^{13-15}$ Although HSV-1 DNA and antigen were found more frequently in groups $1 \mathrm{~A}$ and $1 \mathrm{~B}$ (active inflammation), this can be explained by the greater prevalence of patients with HSK in group 1. Similar to the findings of Holbach et $a l,{ }^{13}$ there was no difference in the incidence of HSV-1 DNA from HSK corneas between groups 1 to 2 . Likewise, we found no difference in the incidence of HSV-1 antigen in HSK corneas between groups 1 to 2 -that is, the presence of HSV-1 antigen did not necessarily correlate with the presence of active inflammation.

CORRELATION BETWEEN PCR AND IHC

There was a good overall correlation between PCR and IHC. It is unlikely that the variation between PCR and IHC is due to the greater sensitivity of PCR than IHC, as this would have resulted in more positive PCR but negative IHC corneas. If, however, HSV-1 causes focal infections in the cornea as suggested by culture studies, ${ }^{3}$ then by randomly dividing the cornea into four segments, disagreement would be expected in $25 \%$ of cases, which is similar to the above results. Indeed Cleator et al found a focal distribution of HSV-1 DNA in sequential sections of a human eye bank cornea. ${ }^{43}$ Openshaw et al ${ }^{11}$ found HSV-1 DNA more frequently in the peripheral than central cornea, which may possibly account for the patients with a history of HSK, but no evidence of HSV-1 DNA and antigen. In addition, the presence of HSV-1 antigen by IHC in the absence of HSV-1 DNA by PCR, may be due to the presence of thymidine kinase negative strains, for which we did not investigate. 
IN SITU HYBRIDISATION, PCR, IHC, AND CULTURE As far as we are aware, Abghari et $a l^{44}$ have provided the only study using ISH in which LATs have been demonstrated in the cornea, and this was in murine corneal cells. They found that five out of 20 pools of dissociated corneal cells hybridised to the probe for LAT while 3\% hybridised with the probe for ICP0. Romanowski et $a l^{45}$ however, failed to find LATs in the corneas of latently infected mice and rabbits using ISH. The detection of LAT using PCR has, however, been more informative. Cook $e t a l^{46}$ found expression of LAT in two out of nine corneas 41 days after inoculation in rabbits untreated with antiviral agents, while O'Brien et al ${ }^{39}$ found LAT expression only in acutely infected but not latently infected rabbit corneas. Kaye et $a l,{ }^{6}$ using RNA-PCR, found expression of LAT in eight out of 10 human HSK corneas. In a study of 18 patients with a history of HSK that was inactive at the time of surgery, and that had been treated with antivirals but not steroids, neither LAT nor transcripts coding for $\alpha, \beta$, or $\gamma$ proteins were detected by ISH. ${ }^{10}{ }^{16}$ Although this is in agreement with our results, the difference between the results for PCR and ISH may be due to the difference in their relative sensitivities, ${ }^{47}{ }^{48}$ particularly if there is very low level expression ${ }^{40}$ and sampling error. The presence, however, of HSV-1 DNA may represent the persistence of defective viral genomes. Indeed, Rong et $a l^{8}$ found that the TK and LAT regions of genes were intact in 13/18 human corneas but that one or other of these regions alone was present in $4 / 18$ corneas. Furthermore, although speculative, it is possible that antigen expression may result from host transcription of viral DNA and class I MHC presentation of the viral protein. ${ }^{49} 50$ The presence, however, of an active inflammatory infiltrate in the corneas of patients with HSK, together with the finding of HSV-1 DNA and antigen, makes a low grade productive infection a distinct possibility. Although LAT has been detected in acutely infected rabbit corneas, ${ }^{39}$ the absence of detectable LAT by ISH may have been due to suppression of the LAT promoter if a low grade productive infection was present or the presence of a LAT deleted strain of HSV-1. ${ }^{19}$ Furthermore, the inability to isolate virus may have resulted from antiviral treatment. Although expression of LAT in the cornea may be dependent on the viral strain, in situ reverse transcriptase PCR is more sensitive than ISH and would be helpful in determining whether low level LAT is expressed in the human cornea.

GRAFT FAILURE-PATIENTS WITH REPEAT CORNEAL GRAFTS

The trend towards an increase of HSV-1 DNA in non-HSK regrafts suggests a possible role for HSV-1 in graft failure. Cockerham et al ${ }^{51}$ found HSV-1 DNA in corneas of two of three patients with primary graft failure, suggesting that HSV-1 may be pathogenic in some cases of primary graft failure. Similarly, Tullo et al ${ }^{52}$ isolated HSV-1 from an eye bank cornea and were able to demonstrate HSV-1 DNA in the fellow cornea after it had been recovered from a failed graft. Including the results of previous studies, ${ }^{67114353}$ gives an overall incidence of HSV-1 DNA in eye bank corneas of $10.1 \%$. Nicholls et $a l^{54}$ and Openshaw et al, ${ }^{11}$ however, were unable to elicit disease in uninfected animals by transplanting corneas containing HSV-1. It is probable, therefore, that HSK post-transplantation arises from host HSV-1 and is unlikely to be accounted for by an infected eyebank cornea. In the HSK repeat grafts, HSV-1 antigen was found predominantly in the stroma. This is in keeping with the findings of Nicholls et al ${ }^{54}$ who found that at the graft-host junction, virus was able to spread to all layers and was not limited to the epithelium.

VARICELLA ZOSTER VIRUS IN THE CORNEA Corneal involvement with VZV can be similar to HSV- $1^{55}$ and can occur without a history of herpes zoster ophthalmicus $(\mathrm{HZO})^{20}$ so that it can be difficult to establish the correct diagnosis clinically. Wenkel et $a l^{21}$ found evidence of VZV antigen in 2/14 corneas by IHC and VZV DNA in $5 / 14$ corneas by ISH, while Mietz et $a l^{20}$ found evidence of VZV DNA in the corneas of $7 / 14$ patients who had a history of HZO. In the present study, evidence of VZV was found significantly more frequently in the corneas of those patients with both clinical and laboratory evidence of HSK. This suggests that infection by both viruses may be more common than is realised, and that infection by one does not preclude co-infection of the cornea by the other. HSV-1 and VZV frequently co-infect the same ganglion ${ }^{56}$ and there does not appear to be any difference in the neurotropic nature of both viruses. ${ }^{55-57}$ While VZV infections are common and the dissemination of VZV may account for its presence in the cornea, it does not explain the increased preponderance in the corneas of patients with a history of HSK. It is possible that an individual may have an inherent predisposition to infection with an $\alpha$ herpesvirus, or that infection with one $\alpha$ herpesvirus increases the susceptibility to infection with another $\alpha$ herpesvirus, such as occurred above with HSV-1 and VZV.

EPSTEIN-BARR VIRUS AND CYTOMEGALOVIRUS IN THE CORNEA

A CMV epithelial keratitis has been reported in patients immunocompromised from HIV infection. ${ }^{27}{ }^{28}$ In immunocompetent individuals however, Crouse et $a l^{7}$ found no evidence of CMV in 32 corneal specimens and, together with the results of this study $(0 / 80)$, this implies that infection of the cornea with CMV probably does not occur in immunocompetent patients. In contrast, EBV DNA has been found in the epithelium of three out of 32 cadaver corneas ${ }^{7}$ and in the central cornea and limbal regions in 3/10 globes. $^{26}$ Although we did not examine donor eyes for EBV, EBV DNA was not found in any of 80 HSK or nonHSK corneas. One possible explanation for this discrepancy is release of virus either due to perimortem agonal stress or from the effects of enucleation. ${ }^{26}$ It is more likely, however, that 
the absence of EBV and CMV DNA in the cornea reflects the lymphotropic and leucotropic nature of these viruses, ${ }^{58}$ as opposed to HSV-1 and VZV, which are dermatropic and neurotropic viruses. ${ }^{57}$ Their absence, however, lends greater weight to the finding of HSV-1 and VZV DNA and points to a keratotropic feature of HSV-1 and VZV.

\section{Conclusion}

We have shown that the clinical diagnosis of HSK can be usefully confirmed by laboratory investigation of corneal specimens removed at keratoplasty. The combination of PCR followed by IHC may be of potential use in obtaining a diagnosis in scarred corneas without a history of HSK. We recommend, therefore, that when analysing the cornea for clinically significant HSV-1 infection, it should initially be screened for HSV-1 DNA by PCR, followed by IHC if HSV-1 DNA is present. The demonstration of at least 50 genome equivalents of HSV-1 DNA (100\% specificity and $28 \%$ sensitivity) or a combination of both HSV-1 DNA and HSV-1 antigen (97\% specificity and $68 \%$ sensitivity) is highly significant. Although culture has $100 \%$ specificity, its low sensitivity of $2 \%$ in this study or $18 \%$ in all studies makes it less useful. The role of ISH is still undetermined and further work is required looking for expression of LAT and other transcripts using in situ PCR. The longer the time from clinically active HSK to surgery, the less likely one is to find evidence of virus. Confirmation of the diagnosis of HSV-1, may be helpful in making decisions on the use of antiviral agents after corneal transplantation.

1 Shimeld C, Tullo AB, Easty DL, et al. Isolation of herpes Br f Ophthalmol 1982;66:643-7.

2 Tullo AB, Easty DL, Shimeld C, et al. Isolation of herpes simplex virus from corneal discs of patients with chronic stromal keratitis. Trans Ophthalmol Soc UK 1985;104:15963.

Easty DL, Shimeld C, Claoue CMP, et al. Herpes simplex virus isolation in chronic stromal keratitis: human and laboratory studies. Curr Eye Res 1987;6:69-74.

4 Coupes D, Klapper PE, Cleator GM, et al. Herpes simplex virus in chronic human stromal keratitis. Curr Eye Res 1986;5:735-8.

5 Cook SD, Aitken DA, Loeffler KU, et al. Herpes simplex virus in the cornea; an ultrastructional study on viral reactivation. Trans Ophthalmol Soc UK 1986;105:634-41

6 Kaye SB, Lynas C, Patterson A, et al. Evidence for herpes simplex virus latency in the human cornea. Br $\mathrm{f}$ Ophthalmol 1991;75:195-200

7 Crouse C, Pflugfelder SC, Pereira IE, et al. Detection of herpes viral genome in normal and diseased corneal epithelium. Curr Eye Res 1990;9:569-81.

8 Rong BL, Pavan-Langston D, Wong QP, et al. Detection of herpes simplex virus thymidine kinase and latencyherpes simplex virus thymidine kinase and latencycorneas by polymerase chain reaction amplification. Invest Ophthalmol Vis Sci 1991;32:1808-15.

9 Cantin EM, Chen J, McNeill J, et al. Detection of herpes simplex virus DNA sequences in corneal transplant recipients by polymerase chain reaction assays. Curr Eye Res 1991;10:15-21

10 Laycock KA, Lee SF, Stulting RD, et al. Herpes simplex virus type 1 transcription is not detectable in quiescen human stromal keratitis by in situ hybridization. Invest Ophthalmol Vis Sci 1993;34:285-92.

11 Openshaw $\mathrm{H}$, McNeill JI, Lin XH, et al. Herpes simplex virus DNA in normal corneas: persistence without viral shedding from the ganglion. 7 Med Virol 1995;46:75-80.

12 Alvarado JA, Underwood JL, Green WR, et al. Detection of herpes simplex viral DNA in the iridocorneal endothelial syndrome. Arch Ophthalmol 1994;112:1601-9.

13 Holbach LM, Font RL, Baehr W, et al. HSV antigens and HSV DNA in avascular and vascularized lesions of human HSV DNA in avascular and vascularized lesions of hun

14 Holbach LM, Font RL, Naumann GOH. Herpes simplex stromal and endothelia keratitis: Granulomatous cell reac- tions at the level of Descemet's membrane, the stroma, and Bowman's layer. Ophthalmology 1990;97:722-8.

15 Holbach LM, Font RL, Wilhelmus KR. Recurrent herpes simplex keratitis with concurrent epithelial and stromal involvement. Arch Ophthalmol 1991;109:692-5.

16 Pepose JS, Lee SF, Stulting RD. Studies of HSV-1 ranscription in human herpetic stromal keratitis. Invest Ophthalmol Vis Sci 1989;30(suppl):215.

17 Perng GC, Zwaagstra JC, Ghiasi H. Similarities in regulation of HSV-1 LAT promoter in corneal and neuronal cells. Invest Ophthalmol Vis Sci 1994;35:2981-9.

18 Leib DA, Bogard CL, Kosz-Vnenchak M, et al. A deletion mutant of the latency-associated transcript of the herpes mutant of the latency-associated transcript of the herpes reduced frequency. F Virol 1989;63:2893-900.

19 Zheng X, Marquart ME, Loustch JM, et al. HSV-1 migration in latently infected and naïve rabbits after penetrating keratoplasty. Invest Ophthalmol Vis Sci 1999;40: $2490-7$

20 Mietz H, Eis-Hubinger AM, Sundmacher R, et al. Detection of varicella-zoster virus DNA in keratectomy specimens by use of the polymerase chain reaction. Arch Ophthalmol 1997;115:590-4.

21 Wenkel H, Rummelt C, Rummelt V, et al. Detection of varicella zoster virus DNA and viral antigen in human cornea after herpes zoster ophthalmicus. Cornea 1993;12:131-7.

22 Maudgal PC, Missottan L, DeClerq E, et al. Varicella-zoster virus in the human corneal endothelium: a case report. Bull Soc Belge Ophtalmol 1980;190:71-82.

23 Pavan-Langston D, Yamamoto S, Dunkel EC. Delayed herpes zoster pseudodendrites, polymerase chain reaction detection of viral DNA and a role for antiviral therapy. Arch Ophthalmol 1995;113:1381-5.

24 Wilhelmus KR, Hamill MB, Jones DB. Varicella disciform stromal keratitis. Am f Ophthalmol 1991;111:575-80.

25 Matoba AY, Wilhelmus KR, Jones DB. Epstein-Barr viral stromal keratitis. Ophthalmology 1986;93:746-51.

26 Chodosh J, Gan YJ, Sixbey JW. Detection of Epstein-Barr virus genome in ocular tissues. Ophthalmology 1996;103: 687-90.

27 Yee RW, Sigler SC, Lawton AW, et al. Apparent cytomegalovirus epithelial keratitis in a cardiac transplant recipient. Transplantation 1991;51:1040-3.

28 Wilhelmus KR, Font RL, Lehmann RP, et al. Cytomegalovirus keratitis in acquired immunodeficiency syndrome. Arch Ophthalmol 1996;114:869-72.

29 Mossman SP, Leib DA, McCarthy K, et al. The effects of 5-azacytidine, 12-o-tetradecanoylphorbol 13-acetate and sodium n-butyrate on reactivation of alphaherpesvirus saimiri from explant cultures of latently infected rabbit dorsal root ganglia. $\mathcal{F}$ Gen Virol 1989;70:2507-12.

30 Saiki RK, Bagawan TL, Horn GT, et al. Analysis of enzymatically amplified $\beta$-globin and HLA-DQ DNA with allele-specific oligonucleotide probes. Nature 1986;324: 163-6.

31 Atkins JT, Demmler GJ, Williamson WD, et al. Polymerase chain reaction to detect cytomegalovirus DNA in the cerebrospinal fluid of neonates with congenital infection. $\mathcal{F}$ Infect Dis 1994;169:1334-7.

32 Sample J, Young L, Martin B, et al. Epstein-Barr virus types and 2 differ in their EBNA-3A, EBNA-3B and EBNA-3C genes. $\mathcal{F}$ Virol 1990;64:4084-92.

33 Kaye, SB, Shimeld C, Grinfeld E, et al. Non-traumatic acquisition of herpes simplex virus infection through the eye. Br f Ophthalmol 1992,76:412-18.

34 Caskey CT, Kruh GD. The HPRT locus. Cell 1979;16:1-9. 35 Hsu SM, Raine L, Fanger H. Use of avidin-biotin peroxidase complex in immunoperoxidase techniques: a comparison between ABC and unlabelled antibody (PAP) procedures. F Histochem Cytochem 1981;29:577-80.

36 Andrew SM, Jasani B. An improved method for the inhibition of endogenous peroxidase non deleterious to lymphocyte surface markers. Application to immunoperoxidase studies on eosinophil-rich tissue preparations. Histochem F 1987;19:426-36.

37 Tullo AB, Shimeld C, Blyth WA, et al. Ocular infection with herpes simplex virus in nonimmune and immune mice. Arch Ophthalmol 1983;101:961-4.

38 Hukkanen V, Heino P, Sears AE, et al. Detection of herpes simplex virus latency-associated RNA in mouse trigeminal ganglia by in situ hybridisation using nonradioactive digoxygenin-labelled

ol 1990;2:70-81. O'Brien WJ, Tsao LS, Taylor JL. Tissue-specific accumulation of latency-associated transcripts in herpes virus-
infected rabbits. Invest Ophthalmol Vis Sci 1998;39:184753.

40 Cantin EM, Hinton DR, Chen J, et al. Gamma interferon expression during acute and latent nervous system infection by HSV type $1 . \mathcal{F}$ Virol 1995;69:4898-905.

41 Cantin EM, Lange W, Openshaw H. Application of polymerase chain reaction assays to studies of herpes simplex virus latency. Intervirology 1991;32:93-100.

42 Remeijer L, Doornenbal P, Geerards AJM, et al. Newly acquired herpes simplex virus keratitis after penetrating keratoplasty. Ophthalmology 1997;104:648-52.

43 Cleator GM, Klapper PE, Dennett C, et al. Corneal donor infection by herpes simplex virus: herpes simplex virus DNA in donor corneas. Cornea 1994;13:294-304.

44 Abghari SZ, Stulting RD, Petrash JM. Detection of herpes simplex virus type 1 latency-associated transcripts in corneal cells of inbred mice by in situ hybridisation. Cornea 1992;11:433-8. 
45 Romanowski E, Araullo-Cruz T, Gordon JY. The controversy over HSV-1 corneal latency: hypothesis or proven fact. Invest Ophthalmol Vis Sci 1990;31(Suppl):219.

46 Cook SD, Hill JM, Lynas C, et al. Latency-associated transcripts in corneas and ganglia of HSV-1 infected rabbits. $B$ f Ophthalmol 1991;75:644-8.

47 Ramakrishnan R, Fink DJ, Jiang G, et al. Competitive quantitative PCR analysis of herpes simplex virus type 1 DNA and latency-associated transcript RNA in latently infected cells of the rat brain. 7 Virol $1994 ; 68: 1864-73$.

48 Ramakrishnan R, Levine M, Fink DJ. PCR-based analysis of herpes simplex virus type 1 latency in the rat trigeminal ganglion established with a ribonucleotide reductasedeficient mutant. F Virol 1994;68:7083-91.

49 Ulmer JB, Donnelly JJ, Parker SE, et al. Heterologous protection against influenza by injection of DNA encoding a viral protein. Science 1993;259:1745-9.

50 Fynan EF, Webster RG, Fuller DH, et al. DNA vaccines: a novel approach to immunization. Int $\mathcal{f}$ Immunopharmacol novel approach

51 Cockerham GC, Kraft AE, McLean IW. Herpes simplex virus. Arch Ophthalmol 1997;115:586-9.
52 Tullo AB, Marcyniuk B, Bonshek R, et al. Herpes virus in a corneal donor. Eye 1990;4:766-7.

53 Morris DJ, Cleator GM, Klapper PE, et al. Detection of herpes simplex virus DNA in donor cornea culture medium by polymerase chain reaction. $\mathrm{Br} \mathcal{F}$ Ophthalmol 1996;80:654-7.

54 Nicholls SM, Shimeld C, Easty DL, et al. Recurrent herpes simplex after corneal transplantation in rats. Invest Ophthalmol Vis Sci 1996;37:425-35.

55 Liesegang TJ. Diagnosis and therapy of herpes zoster ophthalmicus. Ophthalmology 1991;98:1216-29.

56 Mahalingham R, Wellish MC, Dueland AN, et al. Localization of herpes simplex virus and varicella zoster virus DNA in human ganglia. Ann Neurol 1992;31:444-8.

57 Wagner EK, Bloom DC. Experimental investigation of her43 .

58 Rice GPA, Schrier RD, Oldstone MBA. Cytomegalovirus infects human lymphocytes and monocytes: virus expression is restricted to immediate-early products. Proc Natl Acad Sci USA 1984;81:6134-8. 